Journal of Telenursing (JOTING)

Volume 1, Nomor 2, Desember 2019

e-ISSN: 2684-8988

p-ISSN: 2684-8996

DOI: https://doi.org/10.31539/joting.v1i2.966

\title{
PENERAPAN BENTUK PERILAKU ISLAMI TERHADAP KEMAMPUAN PERAWAT MENGIMPLEMENTASI ASUHAN KEPERAWATAN ISLAMI DI RUANG RAWAT INAP
}

\author{
Norman Alfiat Talibo ${ }^{1}$,Tri Kurniati ${ }^{2}$, Giri Widakdo ${ }^{3}$ \\ Sekolah Tinggi Ilmu Kesehatan Muhammadiyah Manado ${ }^{1}$ \\ Universitas Muhammadiyah Jakarta ${ }^{2,3}$ \\ normantalibo@gmail.com ${ }^{1}$
}

\begin{abstract}
ABSTRAK
Tujuan penelitian ini yaitu untuk mengetahui Penerapan bentuk perilaku Islami perawat terhadap kemampuan mengimplementasi asuhan keperawatan Islami di rawat inap Rumah Sakit Islam Jakarta Sukapura tahun 2019. Metode penelitian ini menggunakan pendekatan kuantitatif dengan metode quasi-eksperimental dengan desain penelitian rancangan pre and post with control group design. Hasil Kelompok intervensi dari pengukuran sebelum intervensi di peroleh nilai mean 82,53 dan setelah intervensi 98,68 pada pengukuran minggu ke VI, dengan perbedaan 16,15. Sedangkan nilai rata-rata pada kelompok kontrol antara pengukuran sebelum 75,34 dan pada pengukuran minggu ke VI di peroleh nilai mean 86,06 dengan perbedaan 10,71. Simpulan, penerapan perilaku Islami efektif dalam mengimplementasikan asuhan keperawatan Islami di Rumah Sakit Islam Sukapura Jakarta Tahun 2019.
\end{abstract}

Kata Kunci: Asuhan Keperawatan Islami, Perilaku Islami Perawat

\section{ABSTRACT}

The purpose of this study is to determine the application of nurses' Islamic behavior to the ability to implement Islamic nursing care inpatients at the Sukapura Jakarta Islamic Hospital in 2019. This research method uses a quantitative approach with a QuasiExperimental method with the research design is pre and post with control group design. Results The intervention group from the measurement before intervention was obtained a mean value of 82.53 and after intervention 98.68 at the measurement of week $V I$, with a difference of 16.15. While the average value in the control group between measurements before 75.34 and at the measurement of week VI obtained a mean value of 86.06 with a difference of 10.71. In conclusion, the application of Islamic behavior is effective in implementing Islamic nursing care at Sukapura Islamic Hospital, Jakarta in 2019.

Keywords: Islamic Nursing Care, Islamic Nurse Behavior 


\section{PENDAHULUAN}

Pelayanan keperawatan merupakan suatu bentuk pelayanan profesional sebagai bagian integral dari pelayanan kesehatan yang mempunyai daya ungkit besar terhadap pembangunan bidang kesehatan (PPNI, 2012). Perawat merupakan sumber daya manusia terbesar dalam pelayanan kesehatan di rumah sakit, di mana perawat bekerja selama 24 jam setiap harinya secara bergilir dan berkesinambungan untuk memberikan asuhan keperawatan yang komprehensif dan profesional dan siap membantu pasien setiap saat. Perawat memiliki posisi yang vital di mana sehari-harinya perawat kontak langsung dan mempunyai waktu terbanyak dalam berinteraksi dengan klien sehingga tinggi rendahnya mutu pelayanan kesehatan di rumah sakit salah satunya ditentukan oleh tenaga keperawatan (Farida, 2011) dimana mutu/kualitas pelayanan kesehatan yang diberikan akan mempengaruhi kepuasan pasien (Kucukarslan \& Nadkarni, 2008).

Asuhan keperawatan yang diberikan perawat tidak bisa lepas dari aspek spiritual yang merupakan bagian integral perawat dengan klien. Kebutuhan spiritual merupakan kebutuhan dasar yang dibutuhkan oleh setiap manusia. Apabila seseorang dalam keadaan sakit, maka hubungan dengan Tuhan pun semakin dekat, mengingat seseorang dalam kondisi sakit menjadi lemah dalam segala hal, tidak ada yang mampu membangkitkannya dari kesembuhan, kecuali Sang Pencipta. Dalam pelayanan kesehatan, perawat sebagai petugas kesehatan harus memiliki peran utama dalam memenuhi kebutuhan spiritual (Hamid, 2008).

Penting bagi perawat untuk memahami konsep yang mendasari kesehatan spiritual. Spiritualitas merupakan suatu konsep yang unik pada masing-masing individu yang akhir-akhir ini banyak dipertimbangkan dalam proses perawatan. Hal inididasari asumsi bahwa aspek spiritualberkontribusi dalam menentukan kebahagiaan hidup seseorang. Dengan demikian, perawat juga perlu memahami keterkaitandimensi fisik, psikologis, dan kebudayaan dengan aspek spiritual dalam upaya perbaikan kualitas hidup pasien (Hidayat, 2004).

Perawat sebagai orang pertama yang secara konsisten selama 24 jam menjalin kontak dengan pasien, berperan dalam memberikan pemenuhan kebutuhan spiritual bagi pasien. Salah satu implementasi atau pelaksanaan dari perawatan spiritual adalah dengan menjadi media perantara untuk menghubungkan pemuka agama dengan pasien sesuai dengan keyakinan pasien. Selain itu, sistem asuhan keperawatan yang secara inklusif telah memasukkan aspek spiritualitas mampu mengintegrasikan asuhan yang holistik dengan menghubungkan perawat dengan pemuka agama (Hamid, 2008).

Dimensi spiritual merupakan salah satu dimensi penting yang perlu diperhatikan oleh perawat dalam memberikan asuhan keperawatan. Bahkan, keimanan diketahui sebagai salah satu faktor yang sangat kuat dalam penyembuhan dan pemulihan fisik individu. Mengingat pentingnya peranan spiritual dalam penyembuhan dan pemulihan kesehatan, maka penting bagi perawat untuk meningkatkan pemahaman tentang konsep spiritual agar dapat memberikan asuhan spiritual dengan baik kepada semua klien (Makhija, 2002).

Analisis situasi saat ini pada institusi kesehatan di Indonesia menunjukkan hasil kontradiktif.Sekalipun aspek spiritual dianggap memainkan peranan penting dalam upaya penyembuhan pasien, kenyataannya asuhan keperawatan spiritual belum diberikan oleh perawat secara kompeten. Rankin \& Delashmutt (2006) dalam penelitiannya menemukan bahwa banyak perawat mengakui belum memahami secara jelas dan mengalami kebingunan dalam implementasi konsep spiritualitas dalam asuhan keperawatan. Dalam studi yang lain, Rieg et al., (2006) menyimpulkan banyaknya 
perawat yang mengakui bahwa mereka tidak dapat memberikan asuhan spiritual secara kompeten karena selama masa pendidikannya mereka tidak memperoleh panduan tentang bagaimana memberikan asuhan spiritual.

Isu pelayanan kesehatan yang Islami sampai saat ini terus saja bergulir, hal ini di sebabkan ratusan Rumah Sakit telah didirikan oleh organisasi - organisasi kemasyarakatan Islam, namun sampai saat ini belum ada formulasi yang paripurna tentang pelayanan kesehatan Islami terutama terkait Perilaku Islami seorang Perawat dalam memberikan pelayanan di Rumah Sakit, dan salah satu bentuk pelayanan seorang perawat di rumah sakit adalah terkait pemberian asuhan keperawatan.

Spiritualitas adalah keyakinan dasar adanya kekuatan tertinggi yang mengatur seluruh kehidupan, dan memiliki makna ataupun arti serta tujuan dalam kehidupan (Hendrawan, 2009). Spiritualitas menjadi sumber dukungan dan kekuatan bagi pasien dalam menghadapi penyakitnya. Praktik pemenuhan kebutuhan spiritual pasien memiliki berbagai manfaat, diantaranya meningkatkan pemulihan yang cepat, pencegahan penyakit, dan memberikan ketenangan bagi pasien. Studi yang dilakukan oleh Abu El Noor pada pasien yang dirawat di Intensive Coronary Care Unit dari jalur Gaza menunjukkan bahwa perawatan spiritual dapat menurunkan kecemasan, stress psikologis, depresi, kesedihan, dan dapat meningkatkan kualitas hidup (Abu \& Abu, 2014).

Asuhan keperawatan yang diberikan dalam pemenuhan kebutuhan spiritual dapat dilakukan dengan cara, mengkaji pemahaman klien tentang spiritual, mengkaji kebiasaan klien saat berdoa, memfasilitasi atau membantu klien untuk melakukan rutinitas ibadahnya, dan mendengarkan keluhan klien (Munjirin, 2008).

Penelitian yang di lakukan Rohman pada 30 pasien di tiga Rumah Sakit (RS.Darmais, RSCM, dan RSPAD) menunjukan bahwa perawat belum memperhatikan aspek spiritual.Dari 30 klien yang diobservasi sebanyak $79 \%$ belum mendapatkan pendampingan spiritual pada saat sakit dan ketika dirawat di rumah sakit. Sedangkan sebanyak $21 \%$ mendapatkan pendampingan spiritual, akan tetapi tidak dilakukan oleh perawat melainkan oleh pemuka agama. Hasil tersebut memperlihatkan bahwa perhatian perawat pada aspek spiritual masih belum sesuai dengan apa yang diharapkan (Azzam, 2010).

Survey Kementrian Kesehatan yang diwakili oleh Mamik \& Syarif (2010) mengambil sampel klien rawat inap sebanyak 738 pasien di 23 rumah sakit (umum dan swasta). Survey tersebut dilakukan di lima kota besar di Indonesia dan ditemukan 9 poin masalah, salah satunya didapatkan sebanyak 65,4\% klien mengeluh terhadap sikap perawat yang kurang ramah, kurang simpatik, dan jarang tersenyum.

Hasil wawancara data awal dengan 6 perawat pelaksana di dapatkan bahwa pelaksanaan implementasi Asuhan Keperaatan dengan perilaku Islami masih di pakai dalam melakukan intervensi akan tetapi terkadang juga tidak bahkan tidak sama sekali, di dapatkan juga informasi bahwa Rumah Sakit Islam Sukapura sudah menerapkan pelayanan Islami dalam pemberian pelayanan di rumah sakit untuk memenuhi kebutuhan pelayanan pada klien di instalasi rawat inap, Perawat pelaksana juga mengatakan sudah pernah di berikan sosialisasi terkait Perilaku Islami perawat dan dulunya pernah tersedia buku pedoman tentang perilaku Islami, akan tetapi sudah lebih dari 3 tahun ini sudah tidak pernah terpapar lagi dengan informasi terhadap perilaku Islami. 


\section{METODEPENELITIAN}

Desain penelitian yang digunakan pada penelitian ini adalah desain quasi eksperiment pre and post two group. Dalam penelitian ini terdapat dua kelompok group penelitian di mana yang satu sebagai kelompok kontrol dan yang satunya adalah sebagai kelompok intervensi. populasi dalam penelitian ini adalah semua Perawat pelaksana di Rumah Sakit Islam Jakarta Sukapura ruang rawat inap umum sebanyak 3 ruangan berjumlah 63 Orang perawat, dan Rumah Sakit Islam Jakarta Pondok Kopi ruang rawat inap umum sebanyak 3 ruangan berjumlah 69 orang perawat

Besar sampel yang diperlukan untuk setiap kelompok intervensi dan kelompok kontrol adalah sebesar 32 respondendiambil dengan teknik purposive random sampling

Penelitian ini dilakukan di Rumah Sakit Islam Jakarta Sukapura sebagai kelompok intervensi dan rumah sakit Islami Jakarta Pondok kopi sebagai kelompok kontrol, pertimbangan pemilihan tempat penelitian ini karena Rumah Sakit ini sesuai dengan variabel judul yang akan di teliti, sehingga memungkinkan untuk memperoleh sampel sesuai dengan kriteria inklusi.

Penelitian ini dilaksanakan di mulai dari persiapan penelitian dan proposal di ajukan pada bulan September 2018 - Februari 2019. Dan pengumpulan data di lakukan selama dua 3 bulan yaitu pada bulan maret - mei 2019.

Dalam penelitian ini proses pengambilan dan pengumpulan data diperoleh dengan lembar Kuesioner, observasi perilaku Islami, SPO Perilaku Islami perawat, Modul Perilaku Islami Perawat.Variable dalam penelitian ini adalah variabel independenyaitu Perilaku Islami Perawat,variable dependennya adalah Asuhan Keperawatan Islami.

Sebelum melakukan intervensi peneliti melakukan penilaian pre tes terlebi dahulu pada kedua kelompok kemudian Peneliti melakukan tindakan pemberian Resosialisasi Perilaku Islami selama 1 hari dan di lakukan pengukuran selama 3 kali dalam rentang waktu 2 minggu 4 minggu dan 6 minggu. dan pada kelompok kontrol Peneliti telah melakukan pengukuran terkait Bentuk Perilaku Islami selama 3 kali dalam rentang waktu yang sama juga yaitu selama 2 minggu 4 minggu dan 6 minggu

Analisa data dilakukan secara univariate, bivariate, dan multivariate dengan menggunakan metode analisi General Model Repeated Measures(GLM-RM).

\section{HASIL PENELITIAN Karakteristik Responden}

Karakteristik responden berdasarkan distribusi frekuensi berdasarakan usia terbanyak pada rentan usia 23 - 40 tahun pada kelompok Intervensi yaitu 77,8\% dan 66,7\% pada kelompok kontrol. Distribusi frekuensi jenis kelamin pada kelompok intervensi perempuan lebih banyak dari pada laki-laki yaitu sebesar 78,1\% begitu pula pada kelompok kontrol lebih banyak yang berjenis kelamin perempuan dari pada lakilaki yaitu sebesar 75,0 \%. Distribusi frekuensi responden berdasarkan pendidikan pada kelompok intervensi lebih banyak yang berpendidikan DII Keperawatan yaitu sebesar $75,0 \%$ begitu pula pada kelompok kontrol lebih lebih banyak yang berpendidikan DIII yaitu sebesar 78,1\%. Dan untuk distribusi frekuensi responden berdasarkan lama kerja pada kelompok intervensi lebih banyak yang masa kerjanya $>5$ tahun yaitu sebesar $69,4 \%$ begitu pula pada kelompok kontrol lebih banyak yang masa kerjanya di $>5$ tahun yaitu sebesar $75,0 \%$. 


\section{Analisa Univariat}

Tabel. 1

Nilai Rata-Rata Perilau Islami dalam Implementasi Asuhan Keperawatan Islami pada Kelompok Intervensi dan Kelompok Kontrol $n=32$

\begin{tabular}{lllll}
\hline \multicolumn{1}{c}{ Variabel } & Mean & $\mathrm{n}$ & SD & SE \\
\hline Intervensi & & & & \\
1. Pre Intervensi & 82,53 & 32 & 17,22 & 3,045 \\
2. Pengukuran minggu ke-II & 95,46 & 32 & 17,26 & 3,051 \\
3. Pengukuran minggu ke-IV & 96,50 & 32 & 12,34 & 2,184 \\
4. Pengukuran minggu ke VI & 98,68 & 32 & 11,88 & 2,101 \\
\hline$\quad$ Kontrol & 75,34 & 32 & 8,975 & 1,586 \\
1. Pre pengukuran & 84,81 & 32 & 17,622 & 3,115 \\
2. Pengukuran minggu ke-II & 85,37 & 32 & 17,204 & 3,041 \\
3. Pengukuran minggu ke-IV & 86,06 & 32 & 16,924 & 2,991 \\
4. Pengukuran minggu ke VI & \multicolumn{4}{c}{} \\
\hline
\end{tabular}

Berdasarkan tabel 1 perilaku Islami perawat pada kelompok intervensi dan kelompok kontrol terjadi perkembangan positif, maksudnya dari hasil pengukuran yang di lakukan secara berulang-ulang terbukti untuk kelompok intervensi terjadi peningkatan yang signifikan dari pengukuran Idi dapatkan nilai mean 82,53 dan terus terjadi peningkatan di setiap pengukuran minggu ke II mean 95,46, IV mean 96,50, dan VI mean 98,68. sedangkan untuk kelompok kontrol terjadi peningkatan akan tetapi peningkatan tidak terlalu drastis cenderung stabil di pengukuran minggu I mean 75,34 pengukuran minggu ke II mean84,81, IV mean85,37 dan VI mean 86,06.

\section{Analisa Bivariat}

Tabel. 2

Kenaikan Perilaku Islami Perawat dalam Implementasi Asuhan keperawatan Islami pada Kelompok Intervensi dan Kelompok Kontrol n=32 tahun 2019

\begin{tabular}{lcccc}
\hline \multicolumn{1}{c}{ Variabel } & Mean & $\mathrm{n}$ & SD & P-Value \\
\hline \multicolumn{1}{c}{ Intervensi } & & & & \\
1. Pre pengukuran & 82,53 & 32 & 17,227 & \\
2. Pengukuran minggu ke VI & 98,68 & 32 & 11,885 & 0,000 \\
3. Kenaikan Kontrol & 16,15 & & & \\
\hline Pre pengukuran & 75,34 & 32 & 8,975 & 0,000 \\
1. Pengukuran minggu ke VI & 86,06 & 32 & 16,924 & \\
3. Kenaikan & 10,71 & & & \\
\hline
\end{tabular}

Berdasarkan tabel 2 menunjukan bawa nilai rata-rata perilaku Islami perawat dalam mengimplementasi asuhan keperawatan Islami pada kelompok intervensi pada pengukuran 1 adalah 82,53 dengan standar deviasi 17,22 sedangkan nilai rata-rata untuk kelompok intervensi pada pengukuran minggu ke VI adalah 98,68 dengan standar deviasi 11,88 terjadi kenaikan rata-rata skore perilaku Islami sebesar 16,15. 


\section{Analisa Multivariat}

Tabel 3

Uji Mauchly Perilaku Islami Perawat di Kelompok Intervensi dan Kelompok Kontrol n=32 tahun 2019

\begin{tabular}{cccc}
\hline Kelompok & Mauchly & P-Value & Kesimpulan \\
\hline Intervensi & 0,348 & 0,000 & Tidak varians \\
Kontrol & 0,021 & 0,000 & Tidak varians
\end{tabular}

Berdasarkan tabel 3 diketahui nilai signifikan untuk kelompok intervensi dan kelompok kontrol adalah $0,000<0,05$, dengan kata lain kedua kelompok tidak memenuhi asumsi kesamaan varians.

Tabel. 4

Nilai Greenhouse-Geisser Perilaku Islami Perawat Kelompok Intervensi dan Kelompok Kontrol n=32 Tahun 2019

\begin{tabular}{cccc}
\hline Kelompok & Df & F & P-Value \\
\hline Intervensi & 1,931 & 16,878 & 0,000 \\
Kontrol & 1,166 & 14,328 & 0,000 \\
\hline
\end{tabular}

Berdasarkan tabel 4 diketahui nilai signifikan untuk kelompok intervensi dan kelompok kontrol adalah 0,000 < 0,05, dengan kata lain Ho di tolak dan Ha di terima.

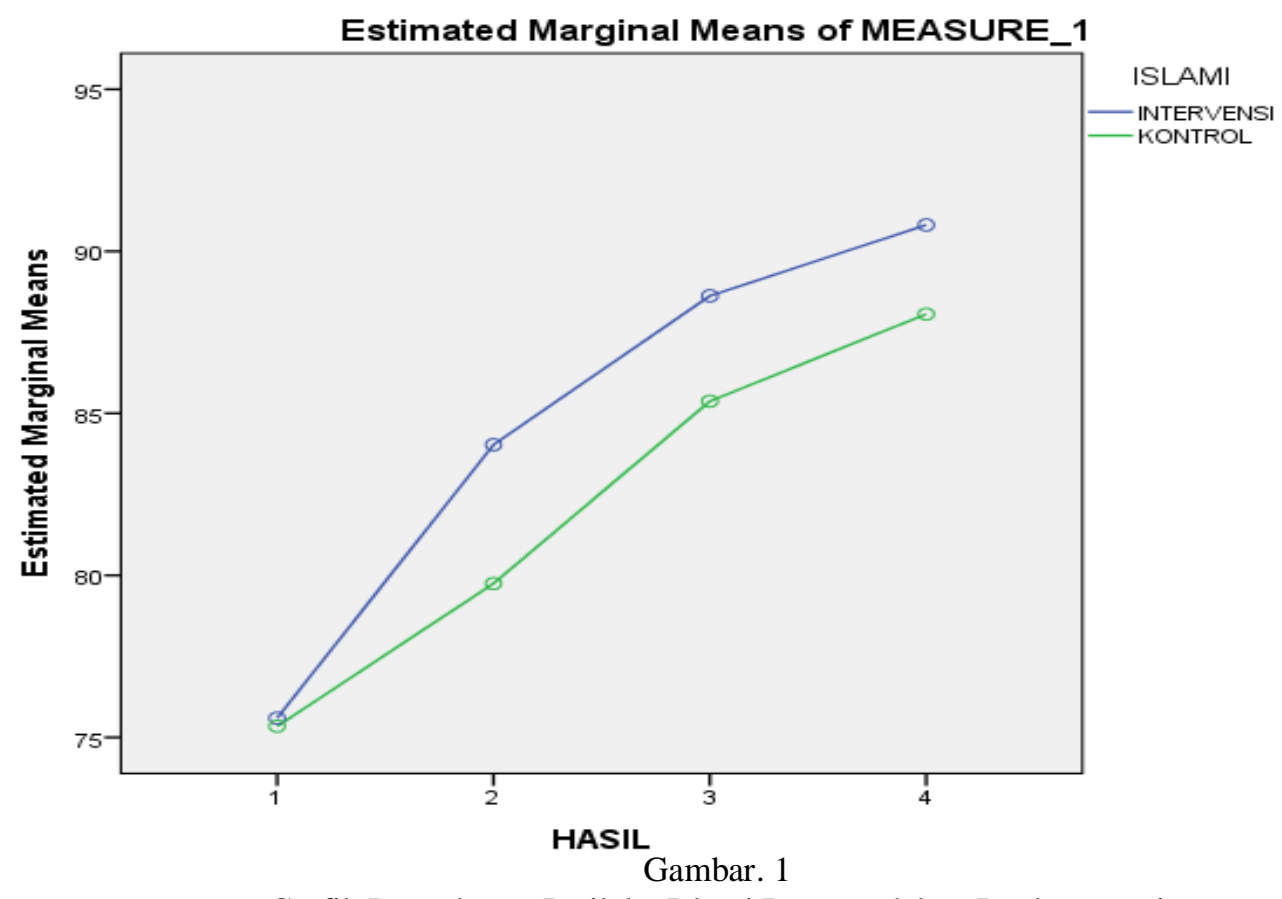

Grafik Pengukuran Perilaku Islami Perawat dalam Implementasi Asuhan Keperawatan Islami 
Berdasarkan gambar 1 tersebut dapat di lihat perubahan untuk kelompok intervensi yang terus meningkat mulai dari pengukuran Minggu II sampai pengukuran ke VI, akan tetapi perubahan tersebut dalam upaya meningkatkan perilaku Islami perawat belum mencapai titik optimal. Hal tersebut dapat di lihat dari garis pada grafik yang belum memperlihatkan garis dasar sampai pengukuran minggu ke VI, sehingga dapat di simpulkan bahwa model perilaku Islami perawat dalam mengimplementasi Asuhan keperawatan Islami sebagai intervensi masih perlu di lanjutkan dan juga pengukurannya sampai di temukan titik optimal.

\section{PEMBAHASAN}

\section{Bentuk Perilaku Islami Perawat dalam Pelaksanaan Implementasi Asuhan Keperawatan Islami}

Hasil pengukuran di dapatkan setelah pemberian intervensi resosialisasi bentuk perilaku islami di Rumah Sakit Islam Sukapura sebagai kelompok intervensi di lakuan pengukuran sebelum intervensi nilai mean dari 82,53 setelah di lakukan intervensi dan di lakukan pengukuran sampai minggu ke VI meningkat menjadi 98,68. Sedangkan untuk kelompok kontrol di Rumah Sakit Islam Pondok Kopi di lakukan pengukuran sebelum penilaian nilai mean dari 75,34 setelah lakukan pengukuran sampai minggu ke VI meningkat menjadi 86,06. Menurut peneliti peningkatan yang terjadi antara kelompok intervensi dan kelompok kontrol sama-sama terjadi walaupun peningkatan pada kelompok kontrol tidak sebesar pada kelompok intervensi, ini menunjukan bahwa pada ada pengaruh terhadap intervensi yang di berikan pada kelompok intervensi.

Penelitian yang dilakukan oleh Amalia (2015) yang menyatakan bahwa sikap perawat tentang asuhan keperawatan spiritual di Ruang Muzdalifah RS Islam Siti Khadijah Palembang berada dalam katagori kurang, karena perawat tidak pernah menanyakan agama pasien dan tidak mengingatkan pasien untuk beribadah, namun memberikan kesempatan bagi pasien yang ingin beribadah.

Menurut Lestari (2015) terdapat beberapa faktor yang dapat mempengaruhi proses bagaimana seseorang bersikap yaitu pengalaman pribadi merupakan hal-hal yang pernah dialami dan dilakukan oleh individu melalui perubahan pengetahuan dan pola pikir yang ada, pengaruh orang lain juga dianggap penting yang dapat mempengaruhi bagaimana individu mengambil sikap terhadap situasi yang ditemuinya, pengaruh kebudayaan yakni bagaimana proses pembentukan sikap pada diri individu, semasa kecil hingga dewasa dan terkait dengan norma-norma di masyarakat, pengaruh media massa juga mempengaruhi sikap seseorang karena mengandung berbagai sugesti yang membuat individu cenderung ikut melakukan hal-hal yang dianggap pantas, dan pengaruh emosional personal dapat mempengaruhi sikap seseorang yaitu dalam kondisi emosional tidak stabil seseorang cenderung dapat melanggar semua norma-norma serta aturan yang dianutnya, termasuk dengan sikap yang dimilikinya.

Pada tahap implementasi, perawat menerapkan rencana intervensi dengan melakukan prinsip-prinsip kegiatan asuhan keperawatan yang meliputi pemeriksaan keyakinan spiritual, fokuskan perhatian pada persepsi pasien terhadap kebutuhan spiritualnya, jangan beranggapan pasien tidak mempunyai kebutuhan spiritual, mengetahui pesan non-verbal tentang kebutuhan spiritual pasien, berespon secara singkat, spesifik, dan aktual, mendengarkan secara aktif dan menunjukkan empati terhadap masalah pasien, membantu memfasilitasi pasien agar dapat memenuhi kewajiban agama, serta memberitahu pelayanan spiritual yang tersedia di rumah sakit (Hawari, 2002). 
Perawat juga berperan sebagai comunicator dalam memberikan implementasi asuhan keperawatan spiritual dengan melakukan aktivitas seperti memberi semangat untuk menggunakan sumber-sumber spiritual jika diperlukan, menyediakan artikel tentang spiritual pilihan pasien, menetapkan penasihat spiritual piihan pasien, mampu mendengar perasaan pasien dan menjadi media komunikasi pasien dalam berdo'a dan ritual keagamaan lainnya (Bulechek et al., 2013).

\section{Perbedaan Bentuk Perilaku Islami Perawat dalam Pelaksanaan Asuhan Keperawatan Islami}

Pada hasil penelitian di pengukuran Pre intervensi, minggu II , minggu IV dan minggu ke VI di kelompok intervensi di simpulkan bahwa pada pre intervensi di dapatkan nilai mean 82,53 dan setelah di berikan intervensi di lakukan pengukuran sampei minggu ke VI naik menjadi 98,68 dengan nilai perbedaan 16,15 hasil uji statistic di dapatkan nilai P-Value 0,000 sehingga dapat di simpulkan ada perbedaan yang signifikan antara pemberian resosialisasi perilaku Islami perawat dalam pengimplementasian asuhan keperawatan Islami bagi responden antara sebelum dan sesudah intervensi. Sedangkan pada keompok kontrol bahwa pada pengukuran pertama di dapatkan nilai mean 75,34 dan pada pengukuran minggu ke VI diperoleh 86,06 dengan nilai perbedaan 10,71 hasil uji statistic di dapatkan nilai $P$-Value 0,000 namun demikian besarnya nilai perbedaan antar pre dan post di Rumah Sakit Islam Pondok Kopi sebagai kelompok kontrol tidak peningkatan di Rumah Sakit Islam Sukapura sebagai kelompok intervensi.

Prabowo \& Pranata (2014) yang menyatakan bahwa tingkat kognitif perawat tentang caring di ruang rawat inap RSU dr. H. Koesnadi Bondowoso berada dalam kategori baik sebesar 56,5\%. Prabowo menyebutkan bahwa hal ini dapat terjadi karena sebagian perawat kurang memahami secara menyuluruh dan mendetail tentang caring, sehingga praktik dan aplikasi caring masih rendah pada perawat. Peneliti Menyimpulkan bahwa Perawat yang memiliki komponen sikap afektif kategori baik cenderung memiliki pandangan emosional yang baik atau memiliki nilai positif terhadap asuhan keperawatan Islami pada pasien. Komponen afektif merupakan komponen sikap yang mempengaruhi kondisi emosional perawat yang mampu mendorong perasaan perawat tentang asuhan keperawatan Islami, yang dapat ditunjukkan melalui mendengarkan keluhan pasien serta memahami ketika pasien tidak mampu atau kesulitan dalam melakukan suatu hal (ibadah). Perawat yang memiliki komponen sikap konatif kategori cukup memiliki kencederungan melakukan tindakan atau berperilaku yang cukup terhadap asuhan keperawatan spiritual pasien.

\section{SIMPULAN}

Simpulan dalam penelitian ini adalah penerapan perilaku Islami efektif dalam mengimplementasikan asuhan keperawatan Islami di Rumah Sakit Islam Sukapura Jakarta Tahun 2019.

\section{SARAN}

Penerapan bentuk perilaku islami dapat diaplikasikan di rumah sakit sebagai model asuhan keperawatan dalam memberikan pelayanan keperawatan dengan memberikan pelatihan kepada semua perawat secara bertahap dan berkesinambungan. Perawat di rumah sakit pada dimensi sabar dan ikhlas serta meningkatkan responsiveness perawat. 


\section{DAFTAR PUSTAKA}

Abu El-Noor, M. K, Abu-El-Noor, N. I. (2014). Importance of Spiritual Care for Cardiac Patients Admitted to Coronary Care Units in the Gaza Strip: Patients Perception. J Holist Nurs, 32(2),104-115. DOI: 10.1177/0898010113503905

Amalia, A. (2015). Peran Perawat dalam Pelaksanaan Standar Asuhan Keperawatan di Ruang Muzdalifah Rumah Sakit Islam Siti Khadijah Palembang Tahun 2014. Jurnal Kesehatan STIK Bina Husada, 10(4)

Azzam, R. (2010). Persepsi Perawat tentang Konsep Spiritualitas dan Asuhan Keperawatan dan Asuhan Keperawatan Spiritual. http;//rohmanpsikfkkumj. wordpres.com. diakses jumat, 30 januari 2015

Bulechek, G. M., Butcher, H. K., Dochterman, J. M., Wagner, C. M. (2013). Nursing Interventions Classification (NIC), Sixth Edition. St. Louis: Elsevier Mosby. Available at https://www.elsevier.com/books/nursing-interventions-classificationnic/

Farida, F. (2011). Effective Leadership and Work Motivation in the Aplication of Nursing Therapeutic Communication, Journal Ners, 6(1), 31-41

Hamid, A. Y. S. (2008). Buku Ajar Aspek Spiritual dalam Keperawatan. Jakarta: Widya Medika

Hawari, D. (2002). Dimensi Religi dalam Praktik Psikiatri dan Psikologis. Jakarta: Fakultas Kedokteran Universitas Indonesia

Hendrawan, S. (2009). Spiritual Management : From Personal Enlightenment Towards God Corporate Governance. Bandung: Mizan

Hidayat, A. A. (2004). Pengantar Konsep Dasar Keperawatan. Jakarta: Salemba Medika

Kucukarslan, K., \& Nadkarni, N. (2008). Evaluating Medicatio-Related Service in Hospital Setting Using the Disconfirmation of Expectation, Research in Social Adm Pharm. 4(1), 12-22 DOI: 10.1016/j.sapharm.2007.01.001

Lestari, T. (2015). Kumpulan Teori untuk Kajian Pustaka Penelitian Kesehatan. Yogyakarta: Nuha Medika

Makhija, N. (2002). Spiritual Nursing. Nursing Journal of India, 93(6), 129-130. Available at https://www.ncbi.nlm.nih.gov/m/pubmed/12649940/?i=6\&from=/10887850/relate d

Mamik, M., \& Syarif, U. (2010). Organisasi dan Manajemen Pelayanan Kesehatan dan Kebidanan, Edisi 1. Surabaya: Zifatama Publishing

Munjirin, M. (2008). Gambaran Peran Perawat dalam Pemenuhan Kebutuhan Spiritual pada Pasien Pre Operasi di Rumah Sakit Umum Daerah Banyumas

PPNI. (2012). Undang-Undang Keperawatan. Naskah Akademik. http://ppnimks.files.wordpress.com/2012/03/ruu-keperawatan-problematika.pdf

Prabowo, E., \& Pranata, A. E. (2014). Asuhan Keperawatan Sistem Perkemihan Edisi 1 Buku Ajar. Yogyakarta: Nuha Medika

Rankin, E. A., \& Delashmutt, M. B. (2006). Finding Spirituality and Nursing Presence: the Student's Challenge. Journal of Holistic Nursing, 24(4), 282-288. Available at https://www.ncbi.nlm.nih.gov/pubmed/17098882

Rieg, L. S., Mason, C. H., \& Preston, K. (2006). Spiritual Care: Practical Guidelines for Rehabilitation Nurses. Rehabilitation Nursing Journal, 31(6), 249-256. Available at https://www.ncbi.nlm.nih.gov/pubmed/17133926 
2019. Journal of Telenursing (JOTING) 1 (2) 324-333

RS.Islam Jakarta Sukapura. (2018). Profil Rumah Sakit Islam Jakarta Sukapura RS.Islam Jakarta Sukapura. (2018). Profil Rumah Sakit Islam Jakarta Pondok Kopi

UMJ. (2018). Pedoman Penulisan Proposal Tesis. Universitas Muhammadiyah Jakarta 